\title{
Konseling Agama Pada Siswa Pecandu Narkoba
}

\author{
Musa Masing \\ Magister Psikologi Pendidikan Universitas Mercu Buana Yogyakarta, Pembina Mental Agama Balai \\ Rehabilitasi, BNN Tanah Merah Samarinda, Alumni STAKN Toraja Tahun 2016 \\ musamasing@gmail.com
}

\begin{abstract}
The purpose of giving counseling for drug addicts students is to correct mistakes that are the new direction and purpose of life in God. Direction of life to God who will be equipped to a better future. In this study using qualitative research with case study techniques. The subjects in this study consisted of 2 students, junior high school students in Samarinda City who were addicted to drugs but were undergoing rehabilitation at the Tanah Merah Samarinda Rehabilitation Center and one person as a mental mentor of religion. This research focuses on Religious Counseling on addicted students. The purpose of this research is to find out the type of religious counseling used for drug addicts students who are undergoing rehabilitation at the BNN Tanah Merah Rehabilitation. The results showed that there were 6 Religious Counseling conducted at the Tanah Merah Samarinda Rehabilitation Center for DT and KS Clients, namely 6 Supportive-Counseling, Confrontational-Counseling, Educative-Counseling, Spiritual-Counseling, Group-Counseling, Preventive-Counseling.
\end{abstract}

Keywords : Counseling Religion, Drus Student Addict

Abstrak: Tujuan pemberian konseling bagi siswa pecandu narkoba adalah memperbaiki kesalahan yang menjadi arah dan tujuan hidup baru di dalam Tuhan. Pengarahan hidup kepada Tuhan yang akan menjadi bekal menuju masa depan yang lebih baik. Dalam penelitian ini menggunakan penelitian Kualitatif dengan Teknik studi kasus. Subjek dalam penelitian ini terdiri dari 2 yaitu Siswa Sekolah Menengah Pertama (SMP) di Kota Samarinda yang menjadi Pecandu narkoba tetapi sedang menjalani rehabilitasi di Balai Rehabilitasi BNN Tanah Merah Samarinda dan satu orang sebagai Pembina mental Agama. Penelitian ini menfokuskan pada Konseling Agama pada siswa pecandu. Tujuan Penelitiannya adalah untuk mengetahui jenis konseling agama yang digunakan bagi siswa pecandu narkoba yang sedang menjalani rehabilitasi di Balai Rehabilitasi BNN Tanah Merah Samarinda. Hasil penelitian menunjukkan bahwa Konseling Agama yang dilakukan di Balai Rehabilitasi BNN Tanah Merah Samarinda kepada Klien DT dan KS ada 6 yaitu Supportive-Konseling, Confrontational-Konseling, Educative-Konseling, Spiritual-Konseling, Group-Konseling, Preventive-Konseling.

Kata kunci : Konseling Agama, Siswa Pecandu Narkoba

\begin{tabular}{llll}
\hline Article History : & Received: 26-05-2020 & Revised: 15-06-2020 Accepted: 18-06-2020
\end{tabular}




\section{Pendahuluan}

"Indonesia darurat narkoba" adalah adalah sebuah slogan yang sedang dicangkan oleh Badan Narkotika Nasional (BNN) sekarang. Slogan ini mengambarkan dengan tepat permasalahan narkoba yang sedang dialami oleh Bangsa Indonesia. Hal itu dilakukan dengan melihat prevalensi tingkat penyalahgunaan narkotika yang semakin hari semakin meningkat mulai dari tingkat ketersediaan, Jumlah pengguna sampai pada para pengguna mulai dari orang tua, pemuda bahkan sampai pada anak-anak termasuk didalamnya adalah peserta didik. Menurut Data BNN pada tahun 2020 periode Januari sampai Juni menunjukkan bahwa jumlah penggunaan narkotika mencapai angka 489 Total tersangka kasus narkoba dan 1708 total pasien penyalahguna yang $85 \%$ diantaranya adalah usia produktif $18-35$ Tahun. ${ }^{1}$ Hal itu dikarenakan pelajar merupakan yang paling rentan menjadi penyalagunaan narkotika karena rasa keingintahuannya yang sangat tinggi terhadap sesuatu yang baru dan menantang.

Seorang siswa yang sedang menjalani masa remaja merupakan segmen kehidupan yang penting dalam siklus perkembangan individu dan merupakan masa transisi yang dapat diarahkan kepada perkembangan masa dewasa yang sehat. ${ }^{2}$ Pada masa transisi ini seorang remaja akan diperhadapkan pada dua pilihan yang berbeda dan sulit yang akan menentukan arah perjalanan kehidupan mereka dimasa yang akan datang misalnya apabila seorang anak belajar dengan baik sesuai dan segala kebutuhannya dapat dipenuhi dengan baik, maka anak akan mengalami kebahagiaan dan kesuksesan dalam menjalani tugas-tugas pada perkembangan berikutnya sebaliknya apabila seorang anak gagal dalam menjalankan tugas dan tanggung jawabnya sebagaimana mestinya, maka akan menimbulkan ketidakbahagiaan pada remaja yang bersangkutan, menimbulkan penolakan masyarakat, dan kesulitan-kesulitan dalam menuntaskan tugas-tugas perkembangan periode berikutnya

Persoalan yang paling umum yang dialami oleh siswa adalah masalah pergaulan. Kitab korintus mencatat "Janganlah kamu sesat: Pergaulan yang buruk merusakkan kebiasaanyang baik" I Korintus 15:33. Dengan pergaulan yang buruk akan membuat seorang anak turut dipengaruhi menjadi buruk contohnya pergaulan yang buruk adalah bergaul dengan para pecandu narkoba. Patjalina Dkk mencatat bahwa Remaja adalah ladang subur penggunaan narkoba hal itu terjadi karena pada saat remaja saat dimana mereka mencari jati diri sehingga merasa tertantang untuk mencoba sesuatu hal yang baru menurut mereka termasuk narkoba. ${ }^{3}$ NAPZA yang kerap kali disebut juga dengan istilah Narkoba yang merupakan kependekan dari Narkotika, Psikotropika dan Zat Adiktif. Kata Narkoba berasal dari Bahasa Inggris yaitu narkotica yang berarti obat bius. Dalam bahasa Yunani disebut dengan narkose yang berarti menidurkan atau membius (Ida Listyarini:2004) Dalam Kamus Bahasa Indonesia memberikan pengertian yang hampir sama dengan pengertian diatas yaitu nar·ko·tik adalah obat untuk menenangkan saraf, menghilangkan rasa sakit, menimbulkan rasa mengantuk, atau merangsang (seperti opium, ganja). ${ }^{4}$

1 bnn.go.id

${ }^{2}$ K. Z. Putro, "Memahami Ciri Dan Tugas Perkembangan Masa Remaja," APLIKASIA Jurnal Aplikasi Ilmu Agama-agama 1 (2017): 25-32, journal.uin-suka.ac.id/pusat/aplikasi.

${ }^{3}$ Laurensia Enny Pantjalina, Muh Syafar, and Sudirman Natzir, "Faktor Mempengaruhi Perilaku Pecandu Penyalahgunaan Napza Pada Masa Pemulihan di Rumah Sakit Jiwa Daerah Atma Husada Mahakam Samarinda," last modified 2016, accessed June 25, 2020, http://pasca.unhas.ac.id.

4 Departemen Pendidikan Nasional, "Narkotika," Kamus Besar Bahasa Indonesia (Balai Pustaka, 2016) 
Di Indonesia UU Mengenai Narkotika dan Psikotropika sudah diatur sedemikan rupa. menurut F. Agsya dalam bukunya tentang Undang-Undang Narkotika dan UndangUndang Psikotropika, UU No. 22 tahun 1997 tentang narkotika, Indonesia secara keseluruhan telah memiliki instrument Undang-Undang sebagai berikut :UU No. 8 tahun 1996 tentang Penegasan Konvensi Tunggal Narkotika 1961 beserta Protokol Perubahan-perubahannya,UU No. 7 tahun 1997 tentang Penegasan Konvensi PBB tentang Pemberantasan Peredaran Gelap Narkotika 1998, UU No. 35 tahun 2009 tentang Narkotika, dimana UU narkotika tersebut merupakan kekuatan hukum untuk penanggulangan dan pemberantasan penyalahgunaan narkotika yang menyerang kalangan remaja maupun dewasa, baik nasional maupun internasional. ${ }^{5}$

Untuk kehidupan yang lebih baik, seorang pecandu narkoba menjalani rehabilitasi supaya kehidupannya bisa kembali produktif termasuk anak-anak (Siswa) yang menjadi kecanduan akibat narkoba. Balai Rehabilitasi BNN Tanah Merah menjadi pusat rujukan Penyalaguna Narkotika di Indonesia Tengah. Dalam proses rehabilitasi inilah seorang anak akan menjalani rehabilitasi selama 90 hari (3 Bulan) yang terud didampingi oleh pihak professional untuk menuntun dan melihat perkembangan setiap hari mulai dari dokter, perawat, psikolog dan Bintal. Peran Pembimbing Mental (Bintal) adalah memberikan Pendidikan dan pengajaran tentang Firman Tuhan kepada anak melalui ibadah dan Konseling. Konseling Agama sendiri dilakukan dengan tujuan supaya anak menjadikan agama (Tuhan) sebagai cermin bagi kehidupannya. Konseling Agama adalah pelayanan terpenting dalam pemulihan seorang pecandu narkoba dalam konseling agama seorang konselor akan menghubungan sifat dasar manusia yang telah jatuh kedalam dosa kepada karya penebusan Allah melalui pengorbanan Anak TunggalNya. Selama proses konseling berlangsung hal utama yang harus diperhatikan adalah sikap dan perilaku seorang konselor saat berhadapan dengan kliennya. Menurut Meier ada 2 aspek yang harus diperhatikan yang akan dihadapi oleh seorang konselor yaitu aspek emosi dan aspek perilaku dari klien dimana perlu adanya penyeimbangan antara kedua aspek tersebut. ${ }^{6}$

Secara umum, tujuan konseling narkoba adalah untuk menyediakan fasilitas untuk melakukan perubahan perilaku penyalahguna, meningkatkan keterampilan penyalahguna untuk menghadapi segala sesuatu yang berhubungan dengan pemulihan kecanduan narkoba, seperti membantu memberikan motivasi untuk mengikuti proses detoksifikasi dan proses pertolongan lainnya. meningkatkan kemampuan penyalahguna dalam mengambil keputusan seperti, meningkatkan kemampuan penyalahguna dalam menjalin hubungan antar pribadi seperti membantu mengatasi pulihnya hubungan dengan anggota keluarga, sehinggga proses penyembuhan dapat berjalan optimal, menyediakan fasilitas untuk pengembangan kemampuan penyalahguna seperti membantu mengatasi situasi yang akan menimbulkan efek fatal bagi penyalahguna narkoba misalkan keinginan bunh diri. ${ }^{7}$ Selain itu, Sarafino menjelaskan bahwa proses pemulihan pecandu narkoba bukanlah suatu proses yang singkat dan dapat dilakukan dengan mudah, sebelum benar-benar dikatakan terbebas dari narkoba, maka dalam

${ }^{5}$ Ach Farid and Mulkiyan, "Terapi Holistik Terhadap Pecandu Narkoba," RELIGI Jurnal Bimbingan Konseling Islam 8, no. 2 (December 2017): 269-292, diakses Juni 25, 2020, https://journal.iainkudus.ac.id/index.php/konseling/article/view/2753/pdf.

6 Paul Meier and Frank, Pengantar Psikologi Dan Konseling (Yogyakarta: ANDI, 2014).

7 Terence T Gorski, Passages Through Recovery: An Action Plan to Recovery (Center City: Hazelden, 1997). 
perjalanannya ada saatnya pecandu mengalami relapse, yang kemungkinan terjadi pada minggu atau bulan pertama setelah berhenti dari penggunaan narkoba. ${ }^{8}$

Dalam penelitian Luluk Indradinul Mufidah mengatakan bahwa tujuan dan fungsi dari Konseling Agama diantaranya: Untuk mengungkapkan kemampuan dasar mentalspiritual dan agama dalam pribadi anak. Berusaha meletakkan kemampuan mentalspiritual tersebut sebagai benteng pribadi anak. Berusaha menanamkan sikap dan orientasi kepada hubungan dalam empat arah yaitu dengan Tuhannya, dengan masyarakatnya, dengan alam sekitarnya dan dengan dirinya sendiri serta Berusaha mencerahkan kehidupan batin. ${ }^{9}$ Artinya bahwa konseling agama dilihat sebagai cermin untuk memperbaiki segala yang salah dalam diri manusia. Dalam penelitian Bucce D Patty dan Rikardo Psianipar menemukan bahwa konseling agama yang baik itu adalah konseling dilaksanakan secara efektif dan efisien yakni, semua komponen dalam suatu lembaga harus bersinergi dan diberdayakan karena Allah menghendaki supaya umatNya mengalami pertumbuhan rohani yang optimal. Pertumbuhan yang dimaksud mencakup pertumbuhan secara kualitas (rohani) dan pertumbuhan kuantitas (jumlah jiwa yang dimenangkan) bagi-Nya. Guna mencapai pertumbuhan seperti itu, Allah telah melengkapi gereja-Nya (hamba-hamba-Nya) dengan potensi (pengetahuan dan pengalaman), bakat, dan karunia-karunia rohani. Tujuannya adalah untuk membawa kemuliaan dan kejayaan bagi kerajaan-Nya. ${ }^{10}$ Karena itulah konseling agama itu sangat diperlukan secara khusu bagi anak/siswa pecandu narkoba

Kendala yang terjadi di Balai Rehabilitasi BNN Tanah Merah Samarinda adalah para pecandu (Siswa Pecandu Narkoba) tidak mengerti dan tidak mengenal arti kebebasan dari dosa. Hal itu terjadi karena efek kecanduan yang membuat mereka tidak mempedulikan lagi relasinya dengan Allah melainkan cenderung mencari kenikmatan untuk memuaskan nafsu mereka yang membuatnya terjatuh semakin dalam oleh ikatan narkotika dan pergaulan bebas. Selain itu para pecandu narkoba belum tahu arah dan tujuan mereka untuk menyampaikan setiap masalah dan keluhan yang mereka alami karena itulah Konseling Agama yang dilakukan oleh Bintal sebagai langkah alternative yang ditempuh untuk kembali mengintrospeksi diri para pecandu berdasarkan Firman Tuhan. Masalah lain adalah para pecandu tidak mendapatkan pendampingan agama selama di rumah mengakibatkan mereka lebih cenderung untuk berkumpul Bersama dengan sesama pemakai dibandingkan bersekutu bersama dengan sesama umat Tuhan di Gereja hal itu terjadi karena kebanyakan dari teman gereja mereka memberikan judgment negative mulai dari cara berpakian, perilaku dalam masyarakat yang sering kali di anggap "Sampah Masyarakat" yang mengakibatkan mereka lebih cenderung mencari tempat atau komunitas yang bisa menerima mereka tanpa ada rasa kaku dan takut mendapatkan stigma.

Fokus Konseling Agama Kristen seorang Bintal terhadap klien anak/siswa di Balai Rehabilitasi BNN Tanah Merah yaitu hasil assessment Bintal dan 6 (Enam) pendapat Gary R Collins yaitu supportive-konseling, confrontational-konseling, educative-

${ }^{8}$ Yustian Sinaga, Irmawati, and Juliana I Saragih, “Efektivitas Group Cognitive Behavioral Therapy dalam Meningkatkan Abstinence Self Efficacy Pecandu Pada Masa Pemulihan di Pusat Rehabilitasi X Kota Medan," Jurnal Psychomutiara 1, no. 1 (2017): 59-71, accessed June 25, 2020, http://e-journal.sarimutiara.ac.id/index.php/Psikologi/article/view/135/152.

${ }^{9}$ Luluk Indarinul Mufidah, "Pentingnya Psikoterapi Agama dalam Kehidupan di Era Modern," Jurnal Lentera: Kajian Keagamaan, Keilmuan dan Teknologi 1, no. 2 (September 30, 2015): 181-196.

${ }^{10}$ Buce D Patty dan Rikardo P Sianipar, "Pastoral Konseling Kepada Narapidana Kristen di Lembaga Pemasyarakatan Cipinang," Jurnal The Way 5, no. 1 (2019): 1-19. 
konseling, spiritual-konseling, group-konseling, preventive-konseling. ${ }^{11}$ Supportif Konseling adalah klien dibantu untuk memahami masalah kehidupannya dan mencoba untuk memahaminya, confrontational-konseling adalah pemberian pemahaman mengenai dosa yang telah dilakukan tetapi tidak menghakimi apa yang telah dilakukan klien tetapi menolong mereka untuk melakukan perbaikan tingkah laku yang selama ini tidak pahami dan tidak mengerti. Educative-konseling adalah menolong klien untuk tetap berpegang pada Firman Tuhan terhadap setiap masalah yang terjadi dan menanamkan nilai spiritual bahwa masalah yang terjadi adalah cara Tuhan untuk membentuk hidup kita menjadi lebih baik. Spiritual-Konseling adalah mengenalkan Tuhan Yesus sebagai Juruselamat apabila mengalami kesulitan atau masalah misalnya tidak bisa belajar dengan baik (konsentrasi) menyalahkan akademis tetapi bisa jadi itu karena adanya kemunduran iman kepada Tuhan. Group-konseling adalah proses konseling yang melibatkan banyak orang yang saling berbagi pengalaman, saling mendukung dan saling menasehati. Preventive-konseling adalah penyembuhhan yang tidak hanya sebatas penyembuhan fisik tetapi juga spiritual atau masalah lain yang menyebabkan seorang anak terikat dengan dosa.

\section{Metode}

Dalam penelitian ini menggunakan metode penelitian kualitatif dimana penelitian kualitatif menurut Lexy J Maleong adalah suatu prosedur penelitian yang menghasilkan deskripsi data berupa kata-kata dari hasil mengamati orang atau perilaku orang. ${ }^{12}$ Lexy J. Maleong menjelaskan bahwa penelitian Kualitatif bertujuan untuk mendapatkan pemahaman serta pengetahuan yang bersifat umum terhadap kehidupan social dari sudut pandang patisipan. Pemahaman yang didapat tidak ditentukan terlebih dahulu melainkan didapat setelah melakukan analisis terhadap kehidupan social yang menjadi fokus penelitian.

Jenis penelitian dalaam tulisan ini adalah studi kasus. Mudjia Rahardjo mendefenisikan studi kasus sebagai suatu rangkaian kegiatan ilmiah yang dilakukan secara intensif, secara rinci, serta mendalam mengenai suatu peristiwa atau aktivitas seorang atau sekelompok orang. ${ }^{13}$ Penelitian jenis studi kasus adalah suatu studi yang bersifat komprehensif, intens, rinci dan mendalam serta lebih diarahkan pada upaya menelaah masalah-masalah atau fenomena yang bersifat kontemporer, kekinian. ${ }^{14}$ Dalam penelitian ini, objek penelitian adalah 2 orang anak/siswa yang menjadi pecandu narkoba yang sedang menjalani rehabilitasi di Balai Rehabilitasi BNN Tanah Merah Samarinda.

Suharsimi menjelaskan bahwa sumber data bisa berupa benda, hal atau orang dimana peneliti mengamati, bertanya atau membaca data. ${ }^{15}$ Dalam hal ini sumber data kualitatif penelitian ini adalah Balai Rehabilitasi BNN Tanah Merah Samarinda, Pembina Mental Agama, Klien/ Siswa Pcandu narkoba yang sedang menjalani rehabilitasi atau benda yang dapat memberikan data bagi peneliti yang digunakan dalam penyusunan penelitian in.

\footnotetext{
${ }^{11}$ Garry R. Collins, Konseling Kristen Yang Efektif, 3rd ed. (Malang: Departement Literatur SAAT, 2015)

${ }^{12}$ Lexy J. Maleong, Metodologi Penelitian Kualitatif (Bandung: Remaja Rosdakarya, 2000), 5.

${ }^{13}$ Mudjia Rahardjo, "Studi Kasus Dalam Penelitian Kualitatif: Konsep Dan Prosedurnya" (Malang: Universitas Islam Negeri Malang, 2013), http://respository.uinmalang.ac.id.//1104/studi-kasus-dalampenelitian-kualitatif.

${ }^{14}$ Robert K. Yin, Studi Kasus Desain Dan Metode (Jakarta: Raja Grafindo Persada, 2018), 1.

${ }^{15}$ Suharsini Arikunto, Prosedur Penelitian Suatu Pendekatan Praktik (Jakarta: Rineka Cipta, 2016),

88.
} 
Untuk mendapatkan data primer dalam penelitian, diperlukan Teknik pengumpulan data seperti:16 Pertama, Wawancara. Wawancara sebagai proses memperoleh informasi dan keterangan untuk tujuan penelitian dengan cara tanya jawab dengan bertatap muka secara langsung dengan menggunakan atau tanpa menggunakan susunana pertanyaan sebagai pedoman wawancara. Dalam hal ini peneliti melakukan wawancara kepada seorang Pembina Mental Balai rehabilitasi untuk mengetahui dan selaku pelaksana konseling agama kepada kedua klien anak pecandu narkoba. Kedua, Observasi. Nasution menjelaskan bahwa observasi dalam penelitian dilakukan untuk memperoleh gambaran mengenai perilaku manusia yang terjadi secara nyata dalam kehidupan sosial. ${ }^{17}$ Observasi dilakukan di Balai Rehailitasi BNN Tanah Merah dengan mengamati konseling agama yang dilakukan Bintal kepada Klien baik dalam bentuk Ibadah, Konseling Individu dan Konseling Kelompok lainnya

\section{Hasil dan Pembahasan \\ Analisis Kasus Hasil Penelitian}

Narkoba (Narkotika dan obat/bahan Berbahaya) adalah obat, bahan, dan zat bukan makanan, yang jika diminum, dihisap, dihirup, ditelan, atau disuntikkan berpengaruh pada kerja otak (susunan saraf pusat) dan sering menyebabkan ketergantungan. Penggunaan narkoba hanya diperuntukkan dalam dunia medis. Penggunaan secara illegal menyebabkan kerusakan fisik, psikis dan spiritual. Kerusakan atau dampak pada spiritual akan merusak secara keselluruhan tugas perkembangan seorang remaja. Irwan Syuhada mengatakan bawa dasar agama yang ditanamkan sejak kecil akan menjadi perisai bagi diri seseorang untuk menolak hal yang sehubungan dengan merusak nilai moral dan spiritual begitupun sebaliknya, anak-anak yang tidak pernah mendapatkan pendidikan agama sangat rawan melakukan tindakan kriminal seperti pecandu narkoba dan minum-minuman keras. Jika seseorng sudah menjadi penyalaguna narkotika, maka tidak akan mempedulikan lagi ibadahnya dan hubungannya dengan Tuhan. Yang ada dalam pikirannya adalah bagaimana cara untuk mendapatkan narkoba sebagai kebutuhan yang utama. Menjadi pecandu narkoba berarti kehilangan damai sejahtera dengan diri sendiri, Allah dan sesama, berdosa (harus pelepasan, pemberesan, pendamaian dengan diri sendiri, Tuhan dan sesama). ${ }^{18}$ Dengan dasar itulah kebanyakan remaja pecandu narkoba tidak lagi mempedulikan kegiatannya sehari-hari sebagai siswa tetapi yang mereka butuhkan adalah cara untuk mendapatkan obat supaya kepuasan dan nafsu duniawi mereka terhadap narkoba bisa terpenuhi. Tidak jarang terlihat dalam masyarakat bahwa mereka anarkis, melakukan pencurian, perampokan, bahkan jambret. Semua itu dilakukan berkaitan dengan efek narkoba itu sendiri yaitu mengalami ketergantungan (Kecanduan) yang menyebabkan seseorang harus untuk memakai dan terus memakai untuk menghilangkan rasa sakit yang mereka alami.

Pembimbing Agama dalam hal ini Pembimbing Mental Agama Kristen yang dikenal dengan sebutan "Bintal" (Bimbingan Mental) memegang peranan penting dalam hal pemberian pembelajaran berbasis agama serta konseling agama bagi remaja yang sedang menjalani rehabilitasi.). Dalam konseling Agama Kristen, seorang Bintal akan memberikan kesempatan kepada kliennya untuk mengungkapkan hal yang dialami

\footnotetext{
16 Maleong, Metodologi Penelitian Kualitatif, 88.

${ }^{17}$ Nasution, Metode Research (Jakarta: Bumi Aksara, 2001), 114

${ }^{18}$ Irwan Syuhada, Faktor Internal dan Intervensi Pada Kasus Penyandang Relaps Narkoba, ed. Irwan Syuhada (Malang: Psychology Forum UMM, 2015).
} 
mulai dari perasaan yang bergejolak, perilaku yang tidak terkontrol secara jujur dan terbuka setelah proses tersebut selesai, Bintal akan memberikan evaluasi terhadap kliennya yang nantinya juga aka nada penyesalan dan pengakuan secara jujur semua perilaku yang menyimpang atau yang tidak sesuai dengan Firman Tuhan. Hal pokok yang harus menjadi perhatian dalam proses konseling adalah tidak terburu-buru dalam melakukan konfrontasi serta mempermasalahkan hal yang diungkapkan oleh kliennya supaya klien merasa diterima dengan baik dengan segala masalah yang mereka bawah.

Tujuan Utama Konseling Kristen adalah untuk menyatakan kebenaran serta memperbaiki kesalahan yang menjadi arah dan tujuan hidup baru didalam Tuhan. Konseling Kristen seluruhnya berpusat pada Allah (Theosentris/Kristosentris) sama seperti Paulus dalam pelayanannya menjadikan Kristus sebagai pusat dalam nasihat dan teguran serta pusat dalam berbagai pengajarannya. Crabb mengatakan bahwa Konselor Kristen harus memiliki pola pikir "memuridkan" terhadap konseli agar pada akhirnya konseli dapat bertumbuh dan dewasa di dalam Kristus melalui segala persoalan yang dihadapi dan bimbingan yang diberikan oleh konselor. ${ }^{19}$ Hambatan utama seorang siswa pecandu narkoba adalah adanya masalah dengan masa lalu (Kecanduan dan perilaku negatif), masa kini yaitu proses yang dihadapi dan masa yang akan datang yaitu stigma negative dari masyarakat tentang dirinya. Hambatan inilah yang sulit menjadikan seorang remaja dengan kecanduan lebih mengenal dan menerima dengan baik arti kedewasaan dan pengampunan didalam Tuhan, oleh karena itulah menjadi tantangan bagi seorang Bintal untuk terus menuntun sampai mencapai kesempurnaan dan kedewasaan diri dialam Tuhan.

\section{Analisis Kasus Konseling Agama Di Balai Rehabilitasi Bnn Tanah Merah Samarinda}

Seperti yang sudah dikemukakan sebelumnya yaitu proses konseling di Balai Rehabilitasi BNN Tanah Merah didasarkan pada analisis kasus dan assessment seorang Bintal kepada klien. Analisisnya dijabarkan sebagai berikut:

\section{Subjek KS}

KS adalah seorang siswa kelas IX di sekolah X di Kota Samarinda. Usia 15 tahun. Jenis pemakaian shabu, lem, ganja dalam rentang waktu selama 2,5 Tahun. Berdasarkan hasil assessment awal, ditemukan beberapa alasan utama penggunaan narkotika yaitu 1) Broken hearth. Diselingkuhi sama pacar yang tidak lain adalah sahabatnya sendiri; 2) Akibat pergaulan bebas (Pergaulan dengan sesama pemakai dalam lingkungan sekolah). Dari hasil assessment alasan penggunaan narkotika, didapatkan dampak penggunaan yaitu: 1) Menjadi kecanduan narkoba; 2) Kecanduan Free Sex; 3) Mencuri barang-barang di rumah; 4) Kondisi psikis terganggu (Sugesti).

\section{Subjek DT}

DT adalah seorang siswa kelas VIII di Kota Palu. Usia 15 tahun. Jenis pemakaian tembakau gorilla, shabu, LL. Berdasarkan hasil assessment Bintal, didapatkan Faktor penggunaan Narkotika adalah: 1) Broken Home. Klien ditinggalkan oleh kedua orang tuanya semenjak umur 6 Bulan dan tinggal dirawat oleh nenek dan kakenya sementara kedua orang tuanya sudah menikah; 2) Factor pergaulan, diajak oleh teman untuk memakai tembakau gorilla karena saat itu klien mengalami depresi akibat dipukuli oleh ayah kandungnya (Sebagai pelarian dari masalah). Dampak yang ditimbulkan adalah

${ }^{19}$ Larry Crabb, Konseling Yang Efektif dan Alkitabiah (Yogyakarta: ANDI, 2015). 
sering berbohong pada nene, uang sekolah dipakai untuk beli narkoba serta menjadi orang yang malas dan introvert.

\section{Konseling Agama Bagi Klien DT Dengan KS Supportif Konseling}

Supportif Konseling adalah klien dibantu untuk memahami masalah kehidupannya dan mencoba untuk memahaminya. Teknik yang digunakan adalah konseling Individu dimana dalam konseling individu, hanya ada seorang klien dengan Bintal yang akan berdiskusi mengenai perasaan bersalah, perasaan negative. Klien DT dan KS menceritakan mengenai jenis pemakaian narkoba, alasan (Faktor) pemakaian serta dampak pemakaian. Dari hasil tersebut, bintal memberikan arahan mengenai masalahnya dengan memfokuskan pada dampak negative dari narkoba yang akan menjadi acuan dalam memberikan gambaran kepada anak tentang narkoba. Bintal memberikan pemahaman secara ideal bahwa dampak negative terbesar narkoba adalah kematian.

Hasil Supportif konseling ini adalah memberikan contoh pada klien DT dan KS mengenai membina hubungan yang lebih baik dengan keluarga, teman, dan lingkungan social secara umum dan mencoba dengan lemah lembut dan tenang menyadari tantangan realita kehidupan yang sedang terjadi supaya DT dan KS mengalami pertumbuhan iman dan kematangan emosi sehingga problem yang mereka hadapi dapat diatasi dengan lebih mudah serta semakin yakin dan percaya atas bimbingan Tuhan dalam menghadapi masalah (Matius 11:28-30). Misalnya dengan cara menyapa konselor atau bintal dengan sebutan "Kakak" dari segi perilaku misalnya memberikan salam sebelum masuk ruangan serta mengucapkan "Permisi" saat lewat didepan temantemannya.

\section{Confrontational-Konseling}

Confrontational-Konseling adalah pemberian pemahaman mengenai dosa yang telah dilakukan. Confrontasi ini menekankan bahwa tidak ada toleransi dengan dosa. Dosa yang menghambat hubungan manusia dengan Allah. Kasus DT ditemukan beberapa konfrontasi dengan dosa yaitu menjadi Pecandu (merusak diri) serta bergaul pada tempat yang salah, untuk klien KS, menjadi kecanduan sex (zinah) dan mencuri. Teknik konseling yang dihunakan adalah konseling kelompok. Dalam konseling kelompok terdapat beberapa orang klien dengan konselor/Bintal. Konseling kelompok tidak menekankan hanya pada satu klien saja tetapi berlaku untuk semua klien. Confrontasi tanpa memberikan judgment tetapi mencarikan contoh dalam Alkitab tentang tidak ada toleransi Tuhan dengan Dosa misalnya perempuan Samaria yang berzinah (Yohanes 4:17-18). Contoh ini diberikan supaya klien memiliki rasa bersalah dalam dirinya sebagai manusia yang telah ditebus dan dikuduskan Oleh Tuhan. Bintal menolong klien supaya mau mengakui dosanya dihadapan Tuhan dan dihadapan sesama serta membantunya untuk memperbaiki tingkah lakunya yang keliru.

Hasil yang diharapkan dari Confrontational Counseling ini adalah klien DT dan KS memahami arti kebermaknaan diri mereka dihadapan Tuhan sebagai ciptaan Mulia, bisa mengenal dan mengerti segala dosa yang mereka lakukan berdasarkan Firman Tuhan mulai dari Kecanduan Narkotika sampai pada kecanduan sex. Tetapi tidak sampai hanya disitu, Klien DT dan KS mau mengakui segala dosa yang mereka perbuat dihadapan Tuhan dan siap untuk memulai hidup baru didalam Tuhan yang penuh dengan kebebasan dari keterikatan dengan dosa. 


\section{Educative-Konseling}

Educative-Konseling adalah menolong klien untuk tetap berpegang pada Firman Tuhan terhadap setiap masalah yang terjadi. Konseling Educative menekankan pada perbaikan tingkah laku yang tidak efektif dan klien dibantu untuk bertingkah laku yang baik dan benar dalam lingkungan baik keluarga maupun masyarakat. Educative Konseling untuk klien DT dan KS adalah belajar dari tingkah laku yang tidak baik dalam masyarakat akibat penggunaan narkoba (Mencuri, Berbohong dan lain-lain). Teknik konseling yang digunakan adalah problem Solving dimana klien diminta untuk menuliskan tingkah laku negatif yang dilakukan pada sebuah kertas dan ditukar dengan sesama klien nantinya klien yang lain akan diminta untuk menuliskan masukan atau perbaikan pada perilaku negative temannya. Semua yang ditulis baik masalah maupun solusi dari teman merupakan pengalaman pribadi klien selama ini. Educative disini dimaksudkan untuk mengajarkan klien berpegang pada kemampuan pemecahan masalah negative dalam lingkungan. Penguatan dari Bintal diakhir adalah I Korintus $15: 33$.

Hasil dari Educative-Konseling adalah Klien DT dan KS mencoba untuk memulai berbicara dengan sopan misalnya menyapa "Selamat Siang kak" memberikan salam sesudah ibadah dan berdoa sebelum membaca Alkitab, Sebelum makan daan sebelum tidur. Educative Konseling disini dimulai dengan hal yang paling sederhana pada Klien DT dan KS karena prinsip dasar konseling ini adalah mencoba belajar dengan hal yang paling kecil. Dengan adanya perubahan yang kecil seperti yang ditunjukkan oleh DT dan KS diharapkan akan bisa juga dilakukan dalam sesame komunitas rehabilitasi bahkan jadi bekal untuk kembali pada masyarakat secara umum.

\section{Spiritual-Konseling}

Spiritual-Konseling adalah mengenalkan Tuhan Yesus Sebagai Juruselamat apabila mengalami kesulitan atau masalah dalam artian berpegang pada Tuhan jika mengalami masalah. Klien Anak biasanya mengetahui bahwa zinah, mencuri dan narkoba itu adalah dosa tetapi hanya sebatas itu. Soal mengapa itu adalah dosa dan dampak dosa sama sekali belum diketahui oleh klien DT dan KS. Spiritual Konseling memandang masalah sebagai bagian dari kemunduran iman kepada Tuhan. Dampak dan akibat dari narkoba yang dialami oleh DT dan KS membuatnya sulit berkonsetrasi alam belajar. Spiritual konseling biasanya membukakan jalan bagi masalah lain dalam kehidupan sehingga begitu masalah tersembunyi muncul, maka bintal akan memperkenalkan Firman Tuhan bagi mereka dan membawa klien lebih menyadari tentang makna kehidupan yang seharusnya (Yohanes 3:16). Pada dasarnya memang setiap konseling agama Kristen menekankan Spiritual atau hubungan dengan Allah dan Manusia serta hubungan antara manusia dengan sesamanya.

Hasil dari Spiritual Konseling bagi Klien DT dan KS adalah semakin memhami bahwa narkoba bukanlah sebuah jalan untuk menyelesaikan masalah yang terjadi melainkan menjadikan Tuhan Yesus sebagai pemberi jalan dalam setiap masalah yang terjadi. Hal ini terlihat bagi klien DT dan KS selama menjalani rehabilitasi mampu menyelesaikan kitab perjanjian baru hanya dalam waktu 45 Hari. Dengan semakin giatnya membaca Alkitab maka dengan sendirinya kesadaran akan timbul dalam diri DT dan KS untuk mengintrospeksi diri sesuai dengan Firman Tuhan yang mereka baca setiap hari dan semakin bertumbuh dalam iman dan pengharapan kepada Tuhan.

\section{Group-Konseling}

Copyright $($ C 2020; PEADA', ISSN: $\quad$ (print), $\quad$ (online) $\mid 28$ 
Group-Konseling adalah proses konseling yang melibatkan banyak orang yang saling berbagi pengalaman, saling mendukung dan saling menasehati. Teknik ini dilakukan dalam ibadah setiap hari. Tidak hanya klien DT dan KS tetapi juga ada klien lain yang ikut berpartisipasi misalnya klien Female (Wanita) dan Klien Male Dewasa. Konseling dilakukan dalam bentuk diskusi singkat menangani pengalaman negative dan positif yang didapatkan selama menjadi seorang pecandu dalam masyarakat. Hal ini dimaksudkan sebagai bentuk refleksi tingkah laku bukan menjadi Sugesti. Group ini dimaksudkan untuk saling menguatkan dan saling meneriman dengan berbagai factor penggunaan dan akibat penggunaan selain itu penekanan konseling ini adalah supaya masing-masing klien bisa mencari tempat/komunitas yang tepat apabila mendapatkan masalah dalam keluarga atau dalam masyarakat.

Hasil dari Group Counseling ini adalah Klien anak (DT dan KS) bisa belajar dari pengalaman kakak-kakaknya yang lain sehingga bisa menjadi panduan nanti dalam menjalani kehidupan apabila menjadi dewasa seperti klien dewasa begitupun bagi klien Dewasa bisa belajar dari klien anak untuk berhati-hati dalam mendidik dan mengatur anaknya supaya tidak menjadi seorang pecandu narkoba. Kedewasaan dan probleme solving mulai Nampak dari KS dan DT saat menghadapi Group Counseling yaitu mempu memberikan Feedback bagi family yang lain tentang suatu masalah yang sedang dihadapi yang bisa menghambat dalam proses pemulihannya. Contohnya memberikan saran "Sebaiknya lebih banyak berdoa dan membaca Alkitab". Hal ini menunjukkan adanya perkembangan mental-Spiritual dalam diri KS dan DT untuk kembali pada Tuhan menyampaikan setiap masalah dibandingkan mengeluh.

\section{Preventive-Konseling}

Preventive-Konseling adalah penyembuhan yang tidak hanya sebatas penyembuhan fisik tetapi juga spiritual atau masalah lain yang menyebabkan seorang anak terikat dengan dosa. Preventif dimaksudkan supaya anak mempunyai bayangan atas masalah yang dihadapi baik dampak negative maupun dampak positif serta pencegahan apabila dampak negative itu terjadi. Misalnya seorang anak apabila sudah selesai menjalani rehabilitasi, diperhadapkan pada masalah social yaitu stigma. Seorang Bintal harus bisa memberikan bayangan tentang stigma, dampak negative dan positif dari stigma serta cara menghadapinya. Hal ini dimaksudkan supaya anak mempunyai bekal untuk survive dalam kehidupan selanjutnya.

Hasil dari preventive konseling ini adalah Klien DT dan KS memandang dari jauh masalah yang akan terjadi jika terus menggunakan narkoba dan jika berhenti. Mereka diperhadapkan pada dua pilihan yang bisa membawa mereka pada kesembuhan dan kesempurnaan didalam Tuhan atau sebaliknya menjadi pecandu seumur hidup. Bagi Klien DT dan KS konseling ini dianggap berhasil karena sudah mampu membedakan hal yang baik dan buruk dengan cerminan Alkitab contohnya "Saya akan lebih rajin berdoa dan membaca Firman Tuhan dan juga akan menjauhi pergaulan yang sebelumnya dan akan rajin ke gereja" dalam hal ini kedua klien sudah mampu untuk memndang kemungkinan hal terburuk yang akan mereka hadapi jika terus menggunakan narkoba dan jika berhenti dan lebih mendekatkan diri kepada Tuhan.

\section{Kesimpulan}

Berdasarkan hasil penelitian yang dilakukan di Balai Rehabilitasi Badan Narkotika Nasional Tanah merah Samarinda mengenai konseling agama kepada Anak (Siswa), Makan dapat disimpulkan bahwa Fokus Konseling Agama pada klien anak di 
Balai Rehabilitasi BNN Tanah Merah Samarinda ada 6 yaitu Supportive-Konseling, Confrontational-Konseling, Educative-Konseling, Spiritual-Konseling, Group-Konseling, Preventive-Konseling. Masing-masing dari konseling ini memberikan hasil berbeda dalam setiap konseling dan terus mengalami kemajuan dalam hal perbaikan perilaku hidup yang sesuai dengan norma-norma umum yang berlaku dalam masyarakat terutama sesuai dengan Firman Tuhan sebagai landasan hidup mereka. Adanya pemahaman yang mendalam mengenai Firman Tuhan yang diperoleh dalam setiap konseling akan menjadikan siswa pecandu narkoba mempunyai arah dan tujuan hidup baru didalam Tuhan dan akan menjadi bekal menuju masa depan yang lebih baik.

\section{Referensi}

www.bnn.go.id

Arikunto, Suharsini. Prosedur Penelitian Suatu Pendekatan Praktik. Jakarta: Rineka Cipta, 2016.

Collins, Garry R. Konseling Kristen Yang Efektif. 3rd ed. Malang: Departement Literatur SAAT, 2015.

Crabb, Larry. Konseling Yang Efektif Dan Alkitabiah. Yogyakarta: ANDI, 2015.

Departemen Pendidikan Nasional. "No Title." Kamus Besar Bahasa Indonesia. Balai Pustaka, 2016.

Enny Pantjalina, Laurensia, Muh Syafar, and Sudirman Natzir. "Faktor Mempengaruhi Perilaku Pecandu Penyalahgunaan Napza Pada Masa Pemulihan Di Rumah Sakit Jiwa Daerah Atma Husada Mahakam Samarinda." Last modified 2016. Accessed June 25, 2020. http://pasca.unhas.ac.id.

Farid, Ach, and Mulkiyan. "Terapi Holistik Terhadap Pecandu Narkoba." RELIGI Jurnal Bimbingan Konseling Islam 8, no. 2 (December 2017): 269-292. Accessed June 25, 2020. https://journal.iainkudus.ac.id/index.php/konseling/article/view/2753/pdf. Maleong, Lexy J. Metodologi Penelitian Kualitatif. Bandung: Remaja Rosdakarya, 2000. Meier, Paul, and Frank. Pengantar Psikologi Dan Konseling. Yogyakarta: ANDI, 2014. Mufidah, Luluk Indarinul. "Pentingnya Psikoterapi Agama Dalam Kehidupan Di Era Modern.” Jurnal Lentera: Kajian Keagamaan, Keilmuan dan Teknologi 1, no. 2 (September 30, 2015): 181-196.

Nasution. Metode Research. Jakarta: Bumi Aksara, 2001.

Patty, Buce D, and Rikardo P Sianipar. "Pastoral Konseling Kepada Narapidana Kristen Di Lembaga Pemasyarakatan Cipinang." Jurnal The Way 5, no. 1 (2019): 1-19.

Putro, K. Z. "Memahami Ciri Dan Tugas Perkembangan Masa Remaja." APLIKASIA Jurnal Aplikasi Ilmu Agama-agama 1 (2017): 25-32. journal.uin-suka.ac.id/pusat/aplikasi.

Rahardjo, Mudjia. "Studi Kasus Dalam Penelitian Kualitatif: Konsep Dan Prosedurnya."

Malang: Universitas Islam Negeri Malang, 2013.

http://respository.uinmalang.ac.id.//1104/studi-kasus-dalam-penelitian-kualitatif.

Sinaga, Yustian, Irmawati, and Juliana I Saragih. "EFEKTIVITAS GROUP COGNITIVE

BEHAVIORAL THERAPY DALAM MENINGKATKAN ABSTINENCE SELF EFFICACY PECANDU PADA MASA PEMULIHAN DI PUSAT REHABILITASI X KOTA MEDAN." Jurnal Psychomutiara 1, no. 1 (2017): 59-71. Accessed June 25, 2020. http://ejournal.sari-mutiara.ac.id/index.php/Psikologi/article/view/135/152.

Syuhada, Irwan. Faktor Internal Dan Intervensi Pada Kasus Penyandang Relaps Narkoba.

Edited by Irwan Syuhada. Malang: Psychology Forum UMM, 2015.

Terence T Gorski. Passages Through Recovery: An Action Plan to Recovery. Center City: Hazelden, 1997.

Yin, Robert K. Studi Kasus Desain Dan Metode. Jakarta: Raja Grafindo Persada, 2018. 